Bożena Tokarz

Uniwersytet Śląski w Katowicach tokarzbozena@gmail.com
Data przesłania tekstu do redakcji: 23.03.2015

Data przyjęcia tekstu do druku: 08.04.2015

\title{
Tłumacz, emocje i przekład
}

Abstract: Ttumacz, emocje i przekład (Translator, Emotions and Translation). "Poznańskie Studia Slawistyczne" 9. Poznań 2015. Publishing House of the Poznań Society for the Advancement of the Arts and Sciences, pp. 381-394. ISSN 2084-3011.

A translator, recreating the original, creatively stimulates her/his intellect, knowledge, senses and emotions. At the same time, $\mathrm{s} /$ he remains in agreement with the emotions presented in the original by assuming with respect to it the only ethically possible attitude, namely empathy. The presence of her/his own emotions in translation, such as sympathy or antipathy, is ethically unacceptable. Emotions occupy an important place in translation because of the difficulty regarding their linguistic transfer, interpretation of their function in the original, intercultural communication differences, and because of the attitude of the translator towards the original. Problems related to emotions concern the art of translation and the need for emotional detachment of the translator, who at the same time needs to maintain an empathic attitude towards the original. Emotions should be considered both on the internal level of the text (the original and the translation) and on the external one - the translator's perspective.

KEYwORDs: emotions; translation; translator; empathy; sympathy

Wyrażanie emocji w drugim języku zależy od dwóch spotykających się osobowości - autora i tłumacza, dwóch języków i dwóch kultur. Przekład jako efekt interakcji prowokuje różne sytuacje wewnątrztekstowe, które wynikają z obowiązku naśladowania przeżycia i ekspresji emocjonalno-intelektualnej obecnej w oryginale, a także sytuacje zewnątrztekstowe, wynikające ze stosunku emocjonalnego, artystycznego oraz intelektualnego tłumacza do poetyki oryginału, emocji w nim wyrażonych, a także do osoby autora. Różnorodność sytuacji wewnątrztekstowych jest związana ze specyfiką leksykalną i gramatyczną obu języków w zakresie znaczenia i kategorii gramatycznych. Transfer oryginału do kultury docelowej dokonuje się w innej strukturze językowej za pomocą często różnych znaczeń i kategorii, przy zachowaniu sensu. Granice substytucji językowo-kulturowej są elastyczne, lecz istnieją po to, by utrzymać względną - bo zależną 
od możliwości językowo-mentalnych - odpowiedzialność wobec autora i jego tekstu. Natomiast ślady sytuacji zewnątrztekstowej, gdy można je odnaleźć w przekładzie, zwykle nie służą jego wartości. Choć tłumacz ma zwykle emocjonalny stosunek do tłumaczonego tekstu, to powinien wyrzec się sympatii czy antypatii do niego na rzecz empatii do oryginału.

Tłumacz odpowiedzialny za transfer oryginału do kultury docelowej stanowi specyficzne medium komunikacyjne między dwiema kulturami. Odtwarzając oryginał, kreatywnie aktywizuje swój rozum, wiedzę, zmysły i emocje. Na poziomie gotowego wytworu jego kreatywność może nosić cechy nowości (ponieważ tak dotąd nie konceptualizowano doświadczenia), oryginalności (ponieważ tłumacz przekroczył możliwości języka rodzimego) oraz niepowtarzalności (ponieważ stworzył własne ścieżki skojarzeniowe w poszukiwaniu dostępu do sensu oryginału). W języku przekładu tłumacz pozostawia ślady swej osobowości, dążąc jednocześnie do rekonstrukcji tekstu wraz z zawartą w nim intencją (Eco 1994), którą odczytuje $z$ analizy semantyczno-stylistycznej i interpretacji oryginału. Kreatywność tłumacza, słusznie kojarzona z wolnością, dotyczy wyłącznie reekspresji, czyli wyrażenia tego samego w innym języku. Jego status w tym zakresie nie może równać się z autorskim, choć niewątpliwie jest kimś w rodzaju autora pomocniczego (Legeżyńska 1999)ํ. Ten, kto dokonuje transferu językowego, zmienia kontekst świata przedstawionego, ponieważ poza znaczeniami uniwersalnymi słowa i wyrażenia posiadają w każdym języku znaczenia kontekstowe, własną pamięć stanowiącą historię swojego użycia oraz służą konceptualizacji zjawisk znanych tylko w danej kulturze, przestrzeni geograficznej, klimacie czy formach organizacji społeczeństwa.

Kreatywność tłumacza jest pobudzana i stymulowana przez ograniczenia i w ograniczeniu, co przypomina kreatywność naukowca. Odkrycia powstają najczęściej wówczas, gdy z paradygmatu myślowego nauki wymyka się obserwacja nieprzystająca do istniejących koncepcji teoretycznych. Thomas Kuhn nazwał to zjawisko anomalią stanowiącą początek innego paradygmatu myślowego, a wraz z nim innego rozumienia człowieka i świata. Zauważalne jest ono dzięki spostrzeżeniu faktu, że znane dotąd reguły i zasady nie dadzą się zastosować we wszystkich sferach

${ }^{1} \mathrm{Cf}$. na temat śladów pozostawionych przez tłumacza. 
rzeczywistości. Nowy paradygmat wytwarza nowe narzędzia poznawcze, które funkcjonują jak okulary, powodując, że zmianie ulega jakość ludzkiego życia, a świat staje sie nie tyle znany, ile widziany (Kuhn 2001). Podobne okulary poznawcze stanowi język: służąc komunikacji, obejmuje siecią znaków różnorodne światy, zjawiska, ludzi i ich zachowania, faunę, florę, przedmioty itp. Będąc środkiem niedoskonałym - doskonale służy komunikacji, sprzyja kształtowaniu się postaw, zachowań i różnego rodzaju poszukiwaniom. W nim znajdują wyraz: rozum, wyobraźnia i uczucie. Językoznawstwo kognitywistyczne, jak również inne pola badawcze z kręgu kognitywistyki, w szczególny sposób opisują wyrażanie kreatywności za pomocą doboru leksemów, posługiwania się konstrukcjami zdaniowymi czy konstruowania określonego porządku argumentacyjnego. Mimo że Mark Turner zwracał uwagę na kreatywną rolę amalgamatów konceptualnych w wyobraźni człowieka, znajdujących wyraz w języku, to nie wyjaśnił mechanizmów kreatywności (Lakoff, Turner 1989). Związane są one z aktywnością językową, stanowiącą jeden z aspektów ludzkiej podmiotowości. Margaret Boden, badaczka sztucznej inteligencji, kognitywistka, twierdzi, że sfery motywacyjne i emocjonalne kreatywności człowieka są wstydliwie pomijane, co wykazali psychiatrzy w dyskusji nad jej książką.

Kreatywność językowa, służąc wyrażaniu rozumienia świata przez podmiot ludzki, wynika ze złożoności ego, określanego przez Carla Gustava Junga jako persona. Persona, łącząc człowieka ze światem, jednocześnie go broni przed nim, aktywizując różne funkcje psychiczne. Jung wyróżnił cztery funkcje psychiczne: myślenie, uczucie, doznanie i intuicję (Jung 1981: 18, 215). Myślenie charakteryzuje intelektualizm, porządek, obiektywizm i harmonia; uczucie - aintelektualizm, emocjonalność, subiektywizm, żywiołowość; doznanie - antyintelektualizm, instynktowność, bezpośredniość, zaskoczenie; intuicję - przeżywanie, odczucie, przeczucie, przeżycie racjonalizujące (kontrola emocji) i kontemplacja. Wszystkie funkcje biorą udział w konceptualizacji doświadczenia zmysłowego i umysłowego. Intuicja i myślenie pełnią rolę obronną, dzięki włączeniu rozumu i rozważań pozwalają na zdystansowanie. Natomiast uczucie i doznanie wciągają jednostkę w rzeczywistość bez możliwości zdystansowania się do niej. W obszarach różnych językowo rzeczywistości znajdują wyraz wszystkie funkcje psychiczne, pozostając w zgodzie z kondycją psychofizyczną i potrzebą jednostki. Nacechowane nimi jest 
każde działanie ludzkie. Rozwój badań z zakresu antropologii, lingwistyki, psychologii, a szczególnie neuropsychologii potwierdza konieczność holistycznego spojrzenia na językową, artystyczną i wszelką inną działalność człowieka, podobnie jak na niego samego (Lakoff 2011: IX-XIV; Damasio 1999). Dlatego, zastanawiając się nad emocjami w przekładzie, należy teoretycznie przyjąć labilność granic denotatów pojęcia emocja znajdujących wyraz w języku.

Istnieje bliskość, lecz nie tożsamość, pojęć: emocja, empatia i sympatia. Reakcje emocjonalne, według Junga, ujawniają takie funkcje psychiczne, jak uczucie i intuicja. Zważywszy jednak, że intuicja racjonalizuje emocje, daje tym samym początek nowemu wzorcowi myślowemu, wchodząc w krąg oddziaływania funkcji myślenia. Na potwierdzenie takiego spostrzeżenia można znaleźć wiele przykładów z dziedziny nauki, sztuki i polityki, ponieważ intuicja pozwala przeczuwać wtedy, gdy jeszcze nie można przewidywać na podstawie danych spekulatywnych i obserwacyjnych. Zatem emocje mają swój wkład także w myślenie. Stanowią odpowiedź ego na rzeczywistość zewnętrzną w postaci konkretnego stanu: poruszenia, wzruszenia, podniecenia, wzburzenia. Jako przeżycia wzbudzane są przez bodźce fizyczne i psychiczne, a więc przeżycia uczuciowe, estetyczne czy intelektualne poprzedzone są doznaniami, wywołując, np.: radość, gniew, miłość, lęk, nienawiść, przyjemność, wstręt, pasję poznawczą. Stanom emocjonalnym towarzyszą stany zmysłowe, określone zachowania i ekspresja językowa.

Empatia związana jest z emocjami za pomocą odbierania bodźców przez czucie, odczucie, doznanie i przeżycie. Nie oznacza stanu pierwotnego, lecz umiejętność wprowadzenia siebie w sytuację kogoś innego: współodczuwania z Innym za pomocą uczuciowego utożsamienia się z nim. Nie jest współczuciem dla Innego, związek z nim jest równorzędny, oparty na rozumieniu bez wartościowania. Stanowi podstawę międzyludzkiej komunikacji, porozumienia, które Elias Canetti nazywa „przejściem między ludźmi” (Canetti 1999: 320). Emmanuel Lévinas (1991) dostrzega w empatii odpowiedzialność wobec Innego, który zasługuje na rozumienie i stworzenie relacji porozumienia. Współodczuwanie, empatia, może mieć charakter emocjonalny, intelektualny, estetyczny i estetyczno-afektywny.

O ile empatia dotyczy relacji międzyludzkich i relacji między przedmiotem a podmiotem na równym poziomie (Głowiński 1997; Płuciennik 
2002; Łebkowska 2003: 83-98), o tyle sympatia jest wyrazem wyraźnie przychylnego, życzliwego i przyjaznego stosunku do Innego w przeżyciu uczuciowym przyjaźni i miłości. Sympatia jest najbardziej nacechowana emocjonalną subiektywnością, przesądzając często o preferowaniu Innego i całkowitym braku krytycyzmu.

Można więc stwierdzić, że pomimo emocjonalności wymienionych relacji ego z rzeczywistością, istnieją między nimi pewne różnice, które szczególnie z punktu widzenia przekładu powinny być zauważalne. Tłumacz konfrontuje się z emocjami w dwóch generalnych sytuacjach: gdy staje wobec konieczności powtórnej konceptualizacji emocji wyrażonych w oryginale oraz - odczuwając przyjemność tłumaczenia jako czynność kreatywną. Wyrażając emocje oryginału w języku docelowym, nie wystarczy poszukiwać słownikowych ekwiwalentów. Oczekiwana jest postawa empatii, by np. wzruszenie, podniecenie, wstręt były wiarygodne i poruszające w przekładzie. Unaocznieniem kompleksowości kompetencyjnej tłumacza jest wypowiedź Tadeusza Komendanta, doświadczonego w przekładach twórczości Bataille’a i innych tekstów francuskojęzycznych. Tłumacz tak pisał o swoich stanach emocjonalno-intelektualnych:

Motto Madame Edwardy wprowadza perspektywę heglowską. Ale od razu zapowiada, że będzie kontynuować nie travail du concept, mrówczą pracę negatywności, lecz „dzieło śmierci”. Hegel odwrócił się, chciał trzymać śmierć na dystans. I ten dystans interesuje Bataille’a, zgodnie z określeniem Derridy „różnica sensu oddzielająca sens od pewnego nonsensu”. On nie odwraca się, choć Madame Edwarda „była całkowicie czarna, prosta, zatrważająca jak jama”. I ta jama, ten grób czeka pośrodku arkady. To, co przetłumaczyliśmy jako ,arkadę”, by ocalić sens przy pomocy gry słów (arkada Arkadia; ,et in Arcadia ego...”), po francusku zostało określone jako arche: Łuk; i tylko to, że słowo odstaje od rzeczy (,arche" to łuk mostowy, łuk architektoniczny to ,arc", zazwyczaj zresztą ,de triomphe”) wskazuje, że nie o sam łuk chodzi, ale o prazasadę wszechrzeczy, arche. „Seul des hommes à passer, le néant de cette arche” - arche jest nicością, drzwiami na obustronną pustkę (Komendant 1985: 272-273).

Esej jest przykładem uważnej interpretacji idei i intencji tekstu przekładanego z wykorzystaniem umiejętności, talentu i wiedzy posiadanej przez tłumacza. Unaocznia ponadto proces tłumaczenia w trzech jego etapach: rozumienia, dewerbalizacji i reekspresji. Faza dewerbalizacji pozwala na potencjalne zaistnienie przekładu: tekst w drugim języku jest już w pamięci tłumacza, choć niepodjęte są jeszcze ostateczne decyzje redakcyjne, 
dotyczące reekspresji. Tłumaczowi towarzyszy wtedy rodzaj „niegotowości"; upewnia się, co do ostatecznego kształtu utworu, dokonuje się w nim weryfikacja zrozumienia w ciągu licznych asocjacji, w czym doznaje jako „drugi autor” (Legeżyńska 1999: 20-46)² chęci utożsamienia się z intencją autora, odczucia jego kreatywności:

W pisaniu Bataille'a nieustannie jest obecna perspektywa kogoś, kogo „skazano na męczarnie”: „,w jego zawężanym horyzoncie każda rzecz, każda twarz nabiera przytłaczającego znaczenia i przyczynia się do zaciśnięcia kleszczy, z których nie czas, by się wyrywać”. (Mogę powiedzieć, że za sprawą Bataille’a doświadczyłem tego stanu, tłumacząc Błękit nieba. [...] Jeśli istotnie Bataille pisze z głębi własnego grobu, oddanie tego po polsku wymaga przyjęcia podobnej perspektywy. [...] w głowie wirowały fragmenty zdań Bataille’a, nie dawały możliwości spoczynku, skazywały na męczarnię. [...] Było jak gdyby tak: jeśli pisanie zażegnuje szaleństwo - „Do pisania zmusza mnie, mam wrażenie, lęk, bym nie oszalał" - wówczas, w moim przypadku, niezbędny demontaż tego pisania owo szaleństwo wyzwala) (Komendant 1985: 277-278).

Intersubiektywny charakter przekładu wynika ze spotkania się dwóch osobowości, należących do odmiennych kultur. Jest to spotkanie oparte na transgresji wyobraźni i wyobrażeń w planie jednostkowym i zbiorowym, która jest możliwa dzięki empatii tłumacza w stosunku do tekstu. Empatia nie wchodzi w zakres kompetencji przekładowych, lecz stanowi o możliwościach komunikacyjnych człowieka. Motywując także makro- i mikrowybory translatorskie, zezwala na przekraczanie granic nie tylko w duchu Bataille'owskim.

Właściwością modelową przekładu obok intertekstualności i pragmatyczności jest intersubiektywność, powstaje ona bowiem w wyniku styku co najmniej dwóch kultur i dwóch osobowości (Tokarz 1998: 10-26). Do powstania przekładu konieczne jest rozumienie, chęć porozumienia warunkowana przez zjawisko empatii, kompetencje i odpowiedzialność w stosunku do Innego. Takiej odpowiedzialności żądał od pisarzy Elias Canetti, mówiąc o „sumieniu słów” (1999). Podobnej odpowiedzialności wymaga przekład w sposób jeszcze bardziej oczywisty niż literatura oryginalna, ponieważ czytelnik nie zastanawia się nad kompetencjami, zdolnościami

\footnotetext{
${ }^{2}$ Autorka opisuje tekstowo-stylistyczne ślady pracy twórczej tłumacza, nazywając go „drugim autorem”. W przeciwieństwie do mnie nie interesuje ją proces tłumaczenia, lecz wyłącznie jego wytwór. Sądzę, że warta podkreślenia jest także potencjalność wytworu obecna w fazie dewerbalizacji.
} 
i wrażliwością tłumacza, lecz odbiera dzieło autora, którego nazwiskiem sygnowana jest książka; rzadko, sprawdzając nazwisko tłumacza, rejestruje go w swojej świadomości. Empatia jest jednym ze środków gwarantujących tę odpowiedzialność.

Empatia różnie bywała i jest definiowana: raz podkreślano jej afektywność odtwórczą, czyli analogiczną u obserwatora w stosunku do obserwowanego, innym razem - afektywność relatywną, a więc nie reprodukcję tych samych emocji, lecz taką na nie reakcję, jak współczucie. Natomiast współodczuwanie sytuowane przez badaczy w zakresie reakcji afektywnych ze skutkiem odtwórczym należałoby rozumieć również jako poczucie związku. Każda z tych reakcji wiąże się - jak pisze Mark H. Davis - z koniecznością przyjęcia roli, wczucia się w kogoś, zaistnienia w jego przestrzeni. Dzięki takiej postawie zjawisko empatii ma charakter poznawczo-afektywny. Bywa więc definiowane również jako ,środek poznania drugiego człowieka poprzez projekcję «ja» w «nie ja». (...) «wejście do wnętrza» kogoś innego (...) (to - B.T.) w pewnym sensie «wyjście naprzeciw», dzięki przemyślanemu wysiłkowi intelektualnemu" (Davis 2001: 15, 21).

Rozszerzanie powszechnego rozumienia empatii jako reakcji emocjonalnej współbrzmiącej z reakcją Innego podkreśla możliwości poznawcze, wynikające z postawy rozumiejącej. Poznawczo-afektywne aspekty empatii pozwalają zrozumieć Innego w procesie doznawania analogicznych skutków afektywnych, a także zrozumieć siebie w przeżywaniu skutków reaktywnych. W jednym i w drugim przypadku przyjmowana jest rola Innego, bez przestawania bycia sobą. Tłumacz przyjmuje rolę autora, nie będąc nim, lecz stając się nim na potrzebę wiarygodności tekstu. Jego odpowiedzialność jest podwójna wobec tekstu i autora oraz wobec rodzimej publiczności czytającej. Rozszyfrowując oryginał, rozbija stereotypy, zachowuje i w miarę możliwości zastępuje je stereotypami rodzimymi, podobnymi pod względem emocjonalno-poznawczym. Przykładem ,podmieniania" stereotypów jest np. zastępowanie idiomu obcego idiomem rodzimym, co jest związane $\mathrm{z}$ ograniczeniem swobody tłumacza przez kulturę, tradycję i język oryginału, z którymi musi poczuć związek, by mogła się nawiązać komunikacja między tekstem oryginału, wyrażonym w innym języku, a czytelnikiem rodzimym. Wszystko to wymaga od niego profesjonalizmu, artyzmu, wrażliwości i umiejętności przechodzenia w Innego i w jego przestrzeń za pomocą języka rodzimego, jego bowiem 
słowo zapewnia oryginałowi istnienie w drugiej kulturze. Szczególny przypadek stanowi reekspresja emocji, nazywanych lub wyrażanych poprzez opisy sytuacji, obrazy, metafory. Nazywanie nie sprawia zwykle trudności, ponieważ emocje związane z uczuciami posiadają - w większości przypadków - ekwiwalenty w drugim języku. Wyrażanie natomiast uzależnione jest od przyjętej w kulturze normy intymności, z którą zmaga się tłumacz, konfrontując się z innością. Naśladowanie zmusza go najczęściej do stosowania substytucji lub redukcji ze względu na czytelnika docelowego. Pójście za oryginałem może grozić wywołaniem u odbiorcy niechęci z różnych powodów: wyuzdania, okrucieństwa, oczywistości, nudy itp. Obawiając się niechęci odbiorcy docelowego, tłumacz powieści Anđelka Vuleticia Dan hapšenja Vile Vukas (Żarliwość i gwatt) pominął znaczny fragment oryginału, a Tadeusz Boy-Żeleński nie przetłumaczył niektórych wulgaryzmów w Mieszczanin szlachcicem Moliera.

$\mathrm{Na}$ decyzje tłumacza ma w tym przypadku niewątpliwy wpływ kultura przyjmująca, lecz nie można wyolbrzymiać jej udziału w rozwiązaniach translatorskich na poziomie reekspresji. Decyzja o przekładzie konkretnego utworu zobowiązuje do odpowiedzialności wobec tekstu źródłowego i jego autora, szczególnie jeżeli dotyczy całości, a nie jego fragmentów. Substytucja i amplifikacja natomiast mają swoje uzasadnienie w możliwościach współodczuwania odbiorcy docelowego z bohaterem, stanem emocjonalnym podmiotu, światem przedstawionym, choć w tym zakresie również wymagana jest ostrożność, by wrażliwość i wiedza czytelnika zostały wzbogacone o odmienność, w której jednocześnie potrafiłby się odnaleźć. Zrobił tak tłumacz Krzeset Ionesco, naśladując tragikomiczną sytuację dwojga starców cierpiących na demencję, chorobę znaczącą dla przedstawionego w dramacie problemu - zaniku komunikacji międzyludzkiej. Dokonał on wielu zmian poszczególnych znaczeń, szczególnie tam, gdzie oryginał eksponuje nieużyteczność słowa jako środka komunikacji. Jednocześnie pozostał wierny oryginałowi, zachowując rytm i instrumentację głoskową, elementy zabawy bohaterów, np. w oryginale: „La Vielle: Est-ce une fleure Monsieur? ou un berceau? ou poirier? ou un corbeau?" (w bezpośrednim tłumaczeniu: Czy to kwiat, proszę pana? Kołyska? Drzewo gruszy? Czy kruk?) (Ionesco 1984: 41), w wydanym przekładzie pojawia się „Stara bierze prezent: Czy to kwiat, proszę pana? Czy kołyska? Drzewo owocowe, walizka?" (Ionesco 1967: 186). 
Zobojętnienie wobec innych, świata i siebie oraz zautomatyzowanie relacji międzyludzkich $\mathrm{w}$ dramacie objawia się zanikiem emocji, wyrażonym przez słowa emocjonalnie nacechowane: une fleure funkcjonuje m.in. w polu znaczeniowym romantycznej miłości; un berceau i un poirier w cyklu narodzin i owocowania oraz un corbeau - wiąże się z symboliką śmierci w kulturze francuskiej. Tłumacz odtworzył porządek skojarzeń, pozwalając sobie na jedno odstępstwo znaczeniowe. Nie szukał ekwiwalentu wyrazu „kruk”. Leksem ten zamienił na słowo „walizka”, co pozwoliło mu zachować rytm wypowiedzi w oryginale, przy jednoczesnym zachowaniu sensu. W tłumaczeniu leksem ,walizka” otwiera nowy dostęp do treści egzystencjalistycznych, ewokowanych przez cykl wyznaczony etapami: zauroczenia, narodzin i wzrostu (owocowania) ku śmierci. Walizka przez zamknięcie może kojarzyć się z przedmiotem trumiennym, podobnie jak skrzynia. Pośrednio przywołuje polską tradycję poetycką - renesansową - fraszkę Jana Kochanowskiego $O \dot{z} y$ wocie ludzkim, w której deizm poety znalazł wyraz w przeświadczeniu o niepewności losu ludzkiego w przeciwieństwie do pewności śmierci. Człowiek wydaje się lalką w otaczającej go rzeczywistości, ponieważ tak jak kukiełkę po zakończeniu spektaklu „Wemkną nas w mieszek, jako czynią łątkom” (Kochanowski 1955: 184). W ten sposób sens tekstu oryginału, dotyczący braku emocji, nazywając rzeczy, przedstawia emocje egzystencjalistyczne.

Redukcja w wyrażaniu emocji powstaje często wtedy, gdy w języku docelowym brakuje nie tyle właściwych leksemów (jak to miało miejsce w tłumaczeniu Bataille’a), ile kłopotów nastręcza gramatyka, kategorie, konstrukcje składniowe lub różni się użycie tych samych kategorii. Z takimi przesunięciami można się spotkać w przekładzie wyrażeń metaforycznych, a więc niestandardowych. W języku polskim czasownik ,wywyższać" jest używany w łączliwości: z kim, czym (wywyższać kogoś, coś); nad kim (wywyższać się nad kimś). W języku słoweńskim podobnie, a jednak znakomita tłumaczka literatury polskiej na język słoweński, Rozka Štefan, dokonała redukcji w wyrażeniu metaforycznym „Wywyższeni ku sobie bez żadnej zasługi” (Szymborska 1997a: 73). Jest to jednak pozorna redukcja wynikająca z systemu i uzusu języka słoweńskiego: „Povišana brez vsake zasluge / katerkoli iz množice, a prepričana, da se je tako moralo zgoditi (...)" (Szymborska 1997b: 54). Szymborska skontaminowała dwa związki łącznościowe czasownika „wywyższać”, wydobywając siłę, 
wzniosłość i nierozerwalność miłości za pomocą wyrażenia przyimkowo-zaimkowego o wysokim stopniu frekwencji w języku polskim. System języka słoweńskiego dysponuje liczbą podwójną czasownika, zawierającą duży ładunek emocjonalny. Jej użycie oznacza wyjątkowość dwojga kochających się ludzi poprzez wzajemną ich przynależność do siebie. Dualis jest równie produktywny w języku słoweńskim, jak formy przyimkowo-zaimkowe w języku polskim. W szczególny sposób nadaje się do wyrażania uczuć, choć używany jest nie tylko w sytuacjach nacechowanych emocjonalnie. W zestawieniu $\mathrm{z}$ brakiem zrozumienia $\mathrm{u}$ innych ze względu na rzadkość silnego uczucia, wydobywa tłumaczka, tak jak to ma miejsce w oryginale - sarkazm wobec świata.

Przystosowanie do kultury przyjmującej nie musi oznaczać swobodnego potraktowania oryginału przez tłumacza, lecz stanowi wynik empatycznego związku z tekstem wyjściowym. Polega on na interpretacji, opartej na wnikliwej analizie języka w kontekście kultury wyjściowej i docelowej. Tylko wtedy substytucja, amplifikacja czy redukcja nie zagrażają integralności sensu, otwierając oryginałowi nowe życie w przekładzie.

Praca tłumacza literatury wymaga wrażliwości i wiedzy, uzupełnionych o talent i pokorę połączoną z dociekliwością wobec oryginału. Związek sprzecznych ze sobą cech czyni z tłumacza także artystę w swej profesji. Dobrzy tłumacze w pełni to sobie uświadamiają, wykazując inwencję i szacunek dla tekstu oryginalnego. Dlatego Tadeusz Komendant pisał, że najlepszym i najdokładniejszym interpretatorem i czytelnikiem jest tłumacz (Komendant 1994: 220). Jego dociekliwość współistnieje z empatią.

Naśladowanie wewnętrznych emocji tekstu poddane jest nie tylko kontroli zawartej w możliwościach systemowych języka przyjmującego oryginał, lecz musi pozostawać w zgodzie z doświadczeniami emocjonalno-komunikacyjnymi przyjętymi w kulturze rodzimej tłumacza, czyli z obowiązującą normą intymności i stylem komunikacji. Dlatego tacy tłumacze literatury polskiej na język słoweński, jak Tone Pretnar i Niko Jež, w celu podkreślenia wiarygodności tłumaczonych utworów, odtwarzając polską emocjonalność i styl komunikacji, wpisują je w reakcje typowe dla słoweńskich zachowań komunikacyjnych. Nie oznacza to jednak, że sfera emocjonalna może ulegać zamierzonej redukcji, jeżeli nie przylega do nawyków kultury przyjmującej. Cel poznawczy przekładu dotyczy w równej mierze wartości intelektualnych, doznaniowych, artystyczno-estetycznych, 
co emocjonalnych. Zaakceptowanie czy choćby zainteresowanie odmiennością w tym zakresie napotyka tylko bardziej żywiołowe i gwałtowne reakcje. $\mathrm{Z}$ tego względu inność wymaga od tłumacza uważnej interpretacji całego utworu, m.in. po to, by mógł ocenić ich funkcję w strukturze całości: czy chodzi o fascynacje emocjami, jak np. w Kochanku Margeritte Duras, czy o decyzję, jak przedstawione emocje mają ukształtować w odbiorcy jakieś przekonania (na zasadzie fascynacji lub sprzeciwu), wartości, kompetencje i wrażliwość na grę prowadzoną przez autora z czytelnikiem. Wówczas na drodze negocjacji ${ }^{3}$ (Tabakowska 2009: 72-73), przewidując reakcje rodzimego czytelnika, tłumacz manipuluje tym, co obce i tym, co swojskie. Powoduje to czasem opóźnienie przekładu niektórych utworów, które zbytnio mogłyby bulwersować czytelników, jak to miało miejsce z twórczością markiza de Sade i w mniejszym stopniu George'a Bataille'a. Obawiając się zbyt silnego wstrząsu obyczajowo-estetycznego, Tadeusz Boy-Żeleński, który udostępnił polskiej kulturze klasykę literatury francuskiej i rozwinął w tłumaczeniach polskie słownictwo erotyczno-emocjonalne, nie odważył się na przekład de Sade’a. Dodać jednak należy, że emocje wraz z tematyką erotyczną i religijną są w szczególny sposób poddawane tabuizacji w kulturach.

Czym innym niż odtwarzanie są emocje tłumacza wobec kultury, literatury, autora czy tekstu przez siebie tłumaczonego. Dokonując wyboru autora i jego utworu - jeżeli ma taką możliwość - kieruje się różnymi względami: wartością, nowością, chęcią uzupełnienia literatury rodzimej, przesłankami artystycznymi i wreszcie przyjemnością. Jego ego wyraża swoje rozumienie kultury, literatury i życia, angażując wszystkie funkcje psychiczne, w których emocjom obok rozumu można przypisać rolę kreatywną. Wybierając, ujawnia swój podziw, fascynacje oznaczające sympatię. Wybór stanowi jedyną możliwość zaznaczania jego sympatii do przedmiotu i jego autora. Sympatia lub antypatia przeniesiona na mikrowybory translatoryczne grozi wejściem w konflikt etyczny z autorem, zakłamaniem tekstu wyjściowego, wprowadzeniem w błąd czytelnika docelowego, czyli jest nieetyczna, ponieważ opiera się na niezracjonalizowanej redukcji. Kierując się sympatią, tłumacz traci oczekiwaną od niego empatię rozumianą jako odpowiedzialność wobec Innego, zawartą w „sumieniu

\footnotetext{
${ }^{3}$ Termin często używany przez Elżbietę Tabakowską.
} 
słów” (Canetti 1999). Czasem wydarza się bowiem, że sympatyzując z autorem, kulturą lub utworem, pomija on znaczne fragmenty tekstu. Przykładem jest tłumaczenie powieści Anđelko Vuleticia Dan hapšenja Vile Vukas (Vuletić 1980; 1994) czy decyzja Tadeusza Boya-Żeleńskiego w kwestii przekładu wulgaryzmów w komedii Molière'a Le Bourgois gentilhomme (Molière 1968: 334-337). W pierwszym przypadku, odczuwając sympatię do kultury wyjściowej, tłumacz pominął drastyczne fragmenty w części epickiej ballady, obawiając się reakcji emocjonalnej odbiorcy polskiego na przedstawione okrucieństwa. W drugim przykładzie tłumacz zlikwidował wulgaryzmy związane z kultem Matki Boskiej, zbyt drastycznie naruszające polskie tabu religijne, w którym sumują się też uczucia rodzinne i patriotyczne. Sympatia do kultury polskiej z kolei objawiała się w działalności translatologicznej Rozki Štefan, lecz tylko w wyborach bez naruszania praw autorskich, w czym przejawiało się jej bogate doświadczenie translatorskie. Pomijanie fragmentów tekstu wyjściowego lub odmienne niż w oryginale zastosowanie tytułów wierszy, esejów czy podrozdziałów stanowi bowiem zawłaszczenie własności autora.

Tłumacz nie może również ujawniać emocji przeciwnych sympatii antypatii czy niechęci, ponieważ powstaje w ten sposób przekład (w najlepszym przypadku) polemiczny, jak w tłumaczeniu wierszy Włodzimierza Majakowskiego przez Juliana Przybosia, o których Edward Balcerzan pisze: „Polski poeta, niepogodzony z ekspresjonistycznymi właściwościami poetyki Rosjanina, z patetycznym «gigantofonem» jego stylu, w swych przekładach owe właściwości nadmiernie wyeksponował. Hiperbolizacja cech przeciwnika jest, jak wiadomo, skutecznym środkiem polemicznym" (Balcerzan 1998: 31). Przekład staje się wówczas parodią lub pastiszem, a więc traci swe podstawowe funkcje, wynikające z jego centralnego miejsca w komunikacji międzykulturowej, jakim jest tworzenie „przejść między ludźmi”".

Emocje zajmują ważne miejsce w przekładzie ze względu na trudności w zakresie ich językowego transferu, odczytania pełnionej funkcji w oryginale, międzykulturowych różnic komunikacyjnych oraz ze względu na stosunek tłumacza do oryginału. Problemy z nimi związane dotyczą sztuki przekładu oraz konieczności dystansu emocjonalnego tłumacza przy jednocześnie empatycznej postawie wobec oryginału. Emocji nie można uniknąć, ponieważ określają nasze bycie w świecie. Można i trzeba mieć 
do nich stosunek empatyczny, który jednocześnie ma charakter etyczny. Trafnie podsumowuje to Elżbieta Tabakowska:

(...) tłumacz musi mieć zdolność odczuwania empatii w każdym możliwym sensie: jak reporter (ponieważ jak autor dobrego reportażu musi umieć „cierpieć z innymi i dzielić ich nadzieje”); jak wrażliwy odbiorca literatury (ponieważ musi umieć współodczuwać z bohaterami swojego autora); jak psycholog (ponieważ musi umieć wywołać w sobie uczucie empatii, co niektórzy nazywają „,wrażliwością na język”) i wreszcie jak dobry negocjator (ponieważ musi umieć przewidzieć reakcje swoich czytelników) (Tabakowska 2009: 72-73).

\section{Literatura}

Balcerzan E., 1998, Literatura z literatury, Katowice.

Boden M., 1995, Creativity and Unpredicability, „SEHR” vol. 4, issue 2, s. 1-18.

Canetti E., 1999, Sumienie słów, przeł. M. Przybyłowska, I. Krońska, posłowie M. Bieńczyk, Kraków.

Damasio A.R., 1999, Błąd Kartezjusza. Emocje, rozum i ludzki mózg, przeł. M. Karpiński, Poznań.

Davis M.H., 2001, Empatia. O umiejętności współodczuwania, przeł. J. Kubiak, Gdańsk.

Eco U., 1994, Lector in fabula, przeł. P. Salwa, Warszawa.

Głowiński M., 1997, Ekspresja i empatia. Studia o młodopolskiej krytyce literackiej, Kraków.

Ionesco E., 1984, Les chaises. Farce tragique. Suivi de L'impromptu de l'Alma, Paris. Ionesco E., 1967, Teatr, t. 1, Krzesła, przeł. J. Kosiński, Warszawa.

Jung C.G., 1981, Archetypy i symbole. Pisma wybrane, wstęp i przekł. J. Prokopiuk, Warszawa.

Kochanowski J., 1955, Dzieła polskie, t. 1, wstęp i przypisy J. Krzyżanowski, Warszawa.

Komendant T., 1985, Batalia, „Literatura na Świecie” nr 10, s. 244-283.

Komendant T., 1994, Władza dyskursu. Michel Foucault w poszukiwaniu samego siebie, Warszawa.

Kuhn T., 2001, Struktura rewolucji naukowych, przeł. H. Ostromęcka, J. Nowotniak, Warszawa.

Lakoff G., 2011, Kobiety, ogień i rzeczy ostateczne. Co kategorie mówią nam o umyśle, red. E. Tabakowska, przeł. M. Buchta, A. Kotarba, A. Skucińska, Kraków.

Lakoff G., Turner M., 1989, More Than Cool Reason: A Field Guide to Poetic Metaphor, Chicago-London.

Legeżyńska A., 1999, Tłumacz i jego kompetencje autorskie, Warszawa.

Lévinas E., 1991, Etyka i nieskończoność. Rozmowy z Philippem Nemo, przeł. B. Opolska-Kokoszka, Kraków. 
Łebkowska A., 2003, Empatia i stereotyp w prozie współczesnej, w: Stereotypy w literaturze (i tuż obok), red. W. Bolecki, G. Gazda, Warszawa, s. 83-98.

Molière, 1968, Dzieła, t. 3, Mieszczanin szlachcicem, przeł., oprac. i wstęp T. Boy-Żeleński, Warszawa.

Molière, 1969, Le Bourgois gentilhomme. La Comtesse d'Escarbagnas, Paris.

Płuciennik J., 2002, Literackie identyfikacje i jej oddźwięki. Poetyka a empatia, Łódź.

Szymborska W., 1997, Widok z ziarnkiem piasku, Poznań.

Szymborska W., 1997, Semenj čudežev, przeł. R. Štefan, J. Unuk, Radovljica.

Tabakowska E., 2009, Ttumaczą się z tlumaczenia, przedmowa A. Szulczyńska, Kraków.

Tokarz B., 1998, Wzorzec, podobieństwo, przypominanie, Katowice.

Vuletić A., 1980, Dan hapšenja Vile Vukas, Zagreb.

Vuletić A., 1994, Żarliwość i gwałt, przeł. G. Łatuszyński, M. Siwkowska-Łatuszyńska, Warszawa. 